\title{
Prisoners' families: issues in law and policy
}

\author{
by Helen Codd
}

\begin{abstract}
The author begins with a brief discussion of current policy in relation to prisoners' families, then considers aspects of prisoners' families interactions with the legal process, taking recent judgments on artificial insemination and mother-and-baby units as case studies.
\end{abstract}

\section{INTRODUCTION}

$\mathrm{T}$

o date, relatively little academic attention has focused on considering the interaction between prisoners' families and law. From the moment a family member is arrested, law underpins and shapes the day-to-day lived experience of many prisoners' partners and children, initially in relation to the police and the trial process, then later during the prison sentence and in relation to subsequent arrangements for release. Prisoners' families are affected not only by the criminal law and sentencing law, but also by family law, child protection law, data protection legislation, housing and welfare law. The research and debates, however, tend to be rooted in sociology or social work, not legal analysis.

\section{THE CURRENT POLICY CONTEXT}

Since the 1960's research has documented the challenges faced by prisoners' partners, children and other kin, including financial difficulties; lack of information and support; housing problems and the effects of social stigmatisation. At the same time examples of innovative good practice in encouraging family ties have been identified and disseminated, such as extended visits, storybook projects, and play schemes (see eg, Light R, (1993), "Why support prisoners' family-tie groups?", The Howard Journal, vol 32, no 4, 322; Light R, (1989) (ed), Prisoners' families: what are the issues?, Bristol Centre for Criminal Justice; Light R, (1992), Prisoners' families: keeping in touch, Bristol Centre for Criminal Justice: Boswell G \& Wedge P, (2001), Imprisoned fathers and their children London, Jessica Kingsley Publishers).

In the last 10 years, there has been growing recognition of the diversity of prisoners' family and kin networks, including discussion of the needs of the families of Black and Asian inmates; partners in gay relationships, and the partners of older prisoners (see eg, Light R, (1995), "Black and Asian prisoners' families", The Howard Journal, vol 34, 209-17; Paylor I \& Smith D, (1994) "Who are prisoners'
131-44; Peelo M, Stewart J, Stewart G, and Prior A, (1991) "Women partners of prisoners", The Howard Journal, vol 30, no 4, 311-27). This research has challenged the stereotype of prisoners' families as usually comprising a male inmate, young female partner and several young children. A recent BBC2 documentary, "Prisoners' families: the silent sentence" shown on June 1, 2004, illustrated another aspects of prisoners' family ties: that is, the impact on prisoners' parents. As a consequence of the "imprisonment binge" and especially the rapid growth in women's imprisonment during the past decade, more and more grandparents find themselves caring for prisoners' children: the needs of grandparent caregivers have been debated and discussed in the USA for quite some time, but the needs this group are only now being recognised in the UK (See for example the guide for grandparent guidegivers published by Islington council. For an outline of the issues, see Cox C, (1999), To grandmother's house we go and stay: perspectives on custodial grandparents, New York, Springer; Dressel P \& Barnhill S K, (1994), "Reframing gerontological thought and practice: the case of grandmothers with daughters in prison", The Gerontologist, vol 34, No 5, 685-91; Minkler M \& Roe K, (1993), Grandmothers as caregivers: raising children of the Crack Cocaine Epidemic, Newbury Park CA, Sage).

It is increasingly being recognised that family ties play a fundamental role in preventing prisoners reoffending, assisting in prisoners' successful community re-entry and ultimately leading to desistance from crime (see eg, Ditchfield J, (1994) Family ties and recidivism, Home Office Research Bulletin No 36: Maruna S, (2001), Making good: how ex-convicts reform and rebuild their lives, American Psychological Association; Maruna S \& Immarigeon R, (2004), After crime and punishment: pathways to offender reintegration, Cullompton, Willan). A number of studies, such as those by Ditchfield and the Social Exclusion Unit, have emphasied the fundamental importance of a stable family in order not only to prevent reoffending but also to minimise the criminogenic effect of a parent's 
imprisonment on children. This has revitalised the debate about the provision of appropriate services and support for families with one member in prison: the probation service has shifted away from work with "uncoerced clients" and voluntary sector organisations are now a significant resource for families.

Whilst the value of maintaining supportive family ties is officially recognised, the practical day-to-day realities of promoting and maintaining these ties can challenge even the most devoted family member. At a time when the prison population is higher than ever, the number of nonlegal visits to prisons has dropped by up to a third (this has been considered by Broadhead J, "Visitors welcome - or are they?", New Law Journal, January 11, 2002, 5: Prison Factfile, Prison Reform Trust, March 2004, London). Julian Broadhead suggests that this decline is due to several factors, including practical problems pre-booking visits; unnecessary strip-searching; prisoners being held a long way from home; and, too often, the perception that visitors to prisons are regarded by prison staff as a nuisance.

Contradictions such as this emerge again and again. Promoting family life has to be balanced against the interests of prison security; facilitating community re-entry has to be balanced against the societal desire to see criminals punished; the desirability of parents maintaining contact with their children has to be balanced against the potential negative effects of children spending time with their parents in a prison environment. Policies and practices vary from prison to prison. Whilst there are many examples of good practice and innovative programmes operating in prisons, ranging from extended visits to play schemes and Relate courses, there are also more negative experiential accounts of difficulties in obtaining information, hostility from prison staff, poor or nonexistent public transport links and inadequate visiting facilities.

In women's prisons, motherhood itself justifies prisons developing new, family-friendly initiatives such as all-day visits: for male inmates, family-friendly projects are justified not purely by reference to parenthood but to research into reoffending (for a brief discussion of recent initiatives to support family ties for women prisoners, see Carlen P and Worrall A, (2004), Analysing women's imprisonment, Cullompton, Willan, 63-6). This reinforces gendered ideologies of women's care. The emphasis on desistance and reintegration of prisoners puts the focus squarely on the inmate, rather than on the family: families are supported because they can play a key role in resettlement, not because of their need for support as a family in their own right. Taken to the extreme, an approach to families based on desistance also raises the the dilemma of the criminal family: if the family is supportive of crime and not desistance, are they undeserving of support?
The gender issues here are also problematic. Research has shown that, regardless of the gender of the inmate, it is women who bear the burdens of caring. Thus when we are talking about "prisoners' families" we are talking about children, and also mainly about women. In one of my previous articles I discussed how prisoners' partners are dependent on the voluntary sector, and how supporting self-help groups, whilst apparently desirable, can reinforce women's caring role and oblige women to care not only for their imprisoned family members but also for other members of prisoners' families. Current initiatives which link family ties with desistance recognise family ties merely as a means to an end. Thus women become co-opted into the process of prisoner resettlement: women become responsible for helping ex-offenders "go straight" and they are supported because of their instrumental value, not because of any commitment to maintaining families for their own sake. This reinforces women's roles as lawabiding carers, and, as the term "prisoner's family" suggests, foregrounds and prioritises the prisoner and not the family.

\section{PRISONERS’ FAMILIES AND THE LAW}

These issues carry through into discussion of prisoners' families and the law. Families are always "in the shadow of the prison" and the prisoner. The legal process is prisonerfocused and there is little official recognition of the needs of prisoners' families in their own right. The research evidence indicates that prisoners' families usually feel peripheral in legal decision-making. For example, for under-18s and those sentenced to DTTO's there is a mandatory requirement that prison governors ensure, where appropriate, that families are given the opportunity to contribute to the sentence planning process: for adult prisoners this is left to the discretion of individual establishments (Paul Goggins, Minister for Prisons and Probation, Hansard, January 20, 2004).

In 2002, the Report of the Social Exclusion Unit Reducing re-offending by ex-prisoners, concluded that:

$$
\begin{aligned}
& \text { "at every stage of a prisoner's movement through the criminal } \\
& \text { justice system, families are largely left out of the decision- } \\
& \text { making process and rarely get the opportunity to support } \\
& \text { prisoners effectively." }
\end{aligned}
$$

Where families wish to challenge the decisions of administrative bodies, a number of legal avenues are open to then. The Prisons Ombudsman, Stephen Shaw, is not empowered to deal with complaints from families: however, judicial review and proceedings under the Human Rights Act 1998 provide a mechanism for challenge, as does the European Court of Human Rights. An ongoing debate in prison law, and one which has led to a number of challenges under the Human Rights Act and in the European Court of Human Rights, concerns the extent to which prisoners retain (or lose) civil rights upon incarceration (see eg, Cheney D, Dickson R, Skilbeck R, 
Uglow S \& John Fitzpatrick, (2001), Criminal Justice and the Human Rights Act 1998, 2nd ed, Jordans, 194).

As Deborah Cheney and others put it:

"it would be untenable to consider that human rights should be suspended at the gates of every prison and reactivated only when a prisoner takes that first step back to freedom".

The classic statement on prisoners' retention of rights is that of Lord Wilberforce in Raymond v Honey [1983] 1 AC 1, subsequently approved by the House of Lords in Simms [2002] 2 AC 115:

"a convicted prisoner....retains all civil rights which are not taken away expressly or by necessary implication”.

I would suggest that an equally valid question is "To what extent do the rights of the families of prisoners survive the sentence of imprisonment?" It is tempting to argue that family members, since they are not convicted, retain all their civil rights and freedoms. In his handbook $A$ human rights approach to prison management, published by the International Centre for Prison Studies, Andrew Coyle writes:

"People who are sent to prison lose the right to free movement but retain other rights as human beings. One of the most important of these is the right to contact with their families. As well as being a right for the prisoner, it is equally a right for the family members who are not in prison. They retain the right of contact with their father or mother, son or daughter, brother or sister who has been sent to prison."

However, some recent cases, such as those on artificial insemination and mother-and-baby units, raise interesting questions of the rights, not only of prisoners but also of family members, and how these rights are to be balanced.

In The Queen on the Application of Mellor v Secretary of State for the Home Department [2001] 3 WLR 533, the Court of Appeal upheld a judgment by Forbes $\mathrm{J}$ dismissing an application from a prisoner who was seeking access to artificial insemination. At the time of the judgment, Gavin Mellor was serving a life sentence, having been convicted of murder in 1995. According to the judgment, the tariff element of his sentence is due to expire in 2006, although it is possible that he may be granted temporary release this year. His wife, whom he married in prison in 1997, will be 31 when his tariff expires in February 2006. Mellor was challenging Home Office policy which, whilst not operating a blanket ban on artificial insemination, allows access to appropriate facilities only in exceptional circumstances. Mellor claimed that the refusal to allow him access to AI facilities breached his right to respect for private and family life under Article 8 of the ECHR, and his right to marry and found a family under Article 12 .

The court rejected Mellor's claim, arguing that one of the purposes of imprisonment was to punish the criminal by depriving him of certain rights and pleasures which he could only enjoy at liberty, including the enjoyment of family life, the exercise of conjugal rights and the right to found a family. In his judgment, Lord Phillips argued that a policy which generally accorded prisoners the right to conceive children by AI would "raise difficult ethical questions and give rise to legitimate public concern", and he discussed the difficulties of creating a de facto singleparent family, contending that it is:

"legitimate, and indeed desirable, that the state should consider the implications of children being brought up in those circumstances when deciding whether or not to have a general policy of facilitating the artificial insemination of the wives of prisoners or of wives who are themselves prisoners."

Professor John Williams, in his thoughtful article about the case, discusses this "natural consequences of imprisonment argument", and also explores the court's reasoning concerning the welfare of the child and the problems of guaranteeing equal treatment for male and female inmates: if AI were granted to male inmates, the same facilities would have to be made available to females (Williams J, (2002), "Have the courts got it right? The Queen on the application of Mellor v Secretary of State for the Home Department, Child and Family Law Quarterly, vol 14, No 2).

He points out that the explicit denial of prisoners' rights to have children appears to have no authority, and contradicts Prison Rule 4. However, the European Court of Human Rights has not yet found a violation of the ECHR where the right of prisoners to procreate was an issue (see Proctor P, "Procreating from prison: evaluating British prisoners' right to artificially inseminate their wives under the United Kingdom's new Human Rights Act and the 2001 Mellor case", Georgia Journal of International and Comparative Law, Winter 2003.

Of course, if prisoners were allowed conjugal visits then there would be no need to seek access to alternative means of conception: however, as Williams points out, the necessary privacy required by such visits could endanger the security of the prison. The same, however, is not true of AI, which offers a method by which a prisoner can exercise his right to found a family which is compatible with the "exigencies of the institutional environment" (see Williams, 2002, above). Whilst purporting to be following Simms, in fact the court turned Simms on its head: instead of accepting that, in Lord Steyn's words, “a .... prisoner ...retains all civil rights which are not taken away expressly or by necessary implication”, Lord Phillips in Mellor seems to suggest that the state's interest in restricting rights is a necessary consequence of impriosnment, which can only be successfully challenged if disproportionate. John Williams is equally dismissive of relying on concerns that it would be inherently problematic to grant access to male inmates because then such access would have to be granted to women, arguing that "to deny a right to somebody simply on the basis that another person may be denied it 
does not rationally further the cause of equal opportunities.”

In an interesting article referred to above, the American academic Pollybeth Proctor considers the impact of the HRA and the Mellor case, with reference to the comparative constitutional position in the USA. She argues that close scrutiny of English jurisprudence and societal values, as well as Convention case law and article provisions, provides ample justification for the understanding of the right to procreate as envisaged in Mellor. She argues that the court in Mellor displayed a commitment to upholding the obligations of the HRA, and concldues that the denial of permission in Mellor "does not signify a breach of the United Kingdom's pledge under the HRA, but rather a cautious and thorough evaluation of their own legal traditions, as well as a fair understanding of the obligations underlying the Act”.

In contrast, John Williams refers to the policy as "the constructive sterilisation of prisoners" and argues that the policy as it stands, as accepted in Mellor, does not provide the appropriate level of respect for prisoners' rights. This view of the Mellor decision is shared by Livingstone and others, who refer to it as "a particularly regressive approach to prisoners' legal rights", arguing that "the level of deprivation which is legitimated by a sentence of imprisonment is considerably harsher [in the UK] than in other countries in Europe" (Owen T, Livingstone S \& Macdonald A, (2003), Prison law, 3rd ed, Oxford University Press).

The Mellor case was brought by a prisoner in relation to his own rights, not that of his partner, although as Mellor pointed out in his initial letter of application, his wife also has a right to found a family. Article 8 appears to protect de facto family life: under Article 12, it could be argued that, following the decision of the ECHR in $X$ \& $Y_{V}$ Switzerland (1978) 13 DR 241, if the applicants are married they have therefore founded a family. Depending on how "founding a family" is defined, if a male prisoner is denied access to facilities for AI, then in order to exercise her own rights his partner would either have to have sex with someone other than her husband, or conceive through formal or informal AID, and thus bear a child of whom her husband would not be the biological father. Thus, the partners of prisoners denied access to AI could themselves challenge the policy on the grounds that their own rights are being infringed.

That said, in the autumn of 2003 the wife of an inmate denied AI failed in an application for judicial review. Lorraine Dickson, herself an ex-prisoner, is the wife of a mandatory lifer whom she befriended via the prison penfriend scheme. Her husband will not be eligible to apply for release on licence until 2009, by which time she will be 51 . Whilst her barrister, Flo Krause, argued that there were "exceptional circumstances" why AI facilities should be provided, Pitchford J said that the Prison Service were justified in refusing such facilities, and in taking into account that their relationship had not been tested outside the prison; the "violent circumstances" of Kirk Dickson's offence (he killed a man in a fight); and the fact that he would not be with the child during a large part of the child's formative years. Lorraine Dickson already has three children by other relationships, and the judge refused to accept that the couple's desire to have a child "trumped all other considerations." In contrast to the approach of the courts in these cases, other inmates serving long sentences have been granted access to AI on the grounds that their wives would be too old to conceive on their release, including in one case, a drug smuggler serving a 17-year sentence ("Prisoners take up their right to father children from prison”, Sunday Times, December 15, 2002, 12).

In reflecting on these cases, it is not easy to explain why the partner of a prisoner can lose her own right to found a family as a consequence of being married to a prisoner, since prisoners' partners have not been convicted and imprisoned. It is, however, well-established in the criminological research literature that prisoners' family members are frequently treated as "guilty by association," stigmatised and taking on a share of the "spoiled identity" of the imprisoned family member (see eg Social Exclusion Unit (2002) Reducing re-offending by ex-prisoners, London, Social Exclusion Unit; Codd H, (1998) "Prisoners' families: the 'forgotten victims," Probation Journal, vol 45, no3, 148-54; Codd H, (2000), "Age, role changes and gender power in family relationships: the experiences of older female partners of male prisoners," Women \& Criminal Justice, vol 12, issue 2/3, 63-93; Codd H, (2002) "The ties that bind: feminist perspectives on self-help groups for prisoners' partners", Howard Journal of Criminal Justice, vol 41, no 4, 334-47; Codd H, (2003) "Women inside and out: prisoners' partners, women in prison and the struggle for identity", Internet Journal of Criminology. http://www.flashmousepublishing.com).

Is this what is happening here? In the Mellor judgment, Lord Phillips cited the case of X v UK (1975) 2 D\&R 105 (cited in the Mellor judgment), a case concerning the denial of conjugal rights, and concluded that "a lawfully convicted prisoner is responsible for is own situation and cannot complain on that account that his right to found a family has been infringed." Could this be applied to claims by prisoners' partners? In both of these cases the women married serving prisoners, and in both of these cases the judges referred to the fact that their relationships had not existed outside the prison. The prison service policy suggests that the situation would be different if the marriage had been pre-existing.

More theoretically, from a feminist criminological perspective, are both Tracey McColl [Gavin Mellor's wife] and Lorraine Dickson transgressive females, who are deemed unsuitable mothers through either their own criminality [Dickson] or, in the case of Tracey McColl, through deviating from the appropriate behaviour of a prison employee by falling in love with an inmate? Is there 
an implied moral judgment here on the wisdom of marrying prisoners? Both men in these cases were mandatory lifers: are the courts distinguishing between murderers and other offenders? The Court of Appeal in Mellor argued that it was better for the well-being of children to be in contact with both parents. I would suggest that it is important to recognise here that although, on a day-to-day basis, one parent is living away from the family home in restrictive circumstances, it does not necessarily follow that they are not in contact with their children, or exercising a meaningful parental role, albeit remotely. After all, there are a number of innovative projects in operation which operate specifically to promote contact between inmates and their children.

Leading on from this, it is useful to remind ourselves of the research evidence, which links family responsibilities and strong family ties to desistance from crime: thus, allowing an inmate to found a family through AI may, in the long-term, contribute to future successful community reentry (see eg the report of the Social Exclusion Unit on reoffending, above, and Williams (2002) above). Although not explicitly stated in Mellor, it is possible that the court were considering the financial implications of creating a child in terms of the potential burden on the state: however, Lorraine Dickson has argued that she is more than capable of supporting a child financially, and she has also arranged shared childcare so that she could work. It could be argued that these judgments reflect a stereotypical concept of family financial support which constructs men as the main household breadwinners: there is nothing to indicate that either of the women in these cases would not be capable of financially supporting any child (and if prisoners earned realistic wages for their work, then a proportion of those wages could be paid as child maintenance).

The situation in relation to mothers who wish to keep their babies with them in prison is rather more complex, but potentially more encouraging in terms of a recognition of the rights of the children of prisoners. In Re $P \& Q(R(P)$ ${ }_{v}$ Secretary of State for the Home Department, $R(Q){ }_{v}$ Secretary of State for the Home Department [2001] 1 WLR 2002), a case heard a few months after Mellor, the Court of Appeal had to consider a challenge brought by two serving prisoners against the policy of the Prison Service [PSO 4801] which prohibited babies from remaining with their mothers in prison after they had reached the age of 18 months. It was held that the Prison Service was entitled to have a policy of this kind, but was not entitled to operate this policy in a rigid fashion, insisting that all children must leave a mother and baby unit by the age of 18 months

"however catastrophic the separation might be in the case of a particular child, however unsatisfactory the alternative placement available for the child, and however attractive the alternative solution of combining daycare outside prison."
The court reached this conclusion for two reasons. The first was because the policy's own declared aim was to promote the welfare of the child. The second ground was that, on the proper application of Article 8, there might be rare exceptions where the interests of mother and child coincide and outweigh any other considerations arising from the fact of the mother's imprisonment and the implications of any relaxation in the policy on the individual prison and the Prison Service generally.

The decision in this case was greeted by Vanessa Munro in her article as "throwing open current prison service policy and practice in this area to critical scrutiny" (Munro V, (2002), "The emerging rights of imprisoned mothers and their children", Child and Family Law Quarterly, vol 14, no 3). In this case, under the Children Act the court was legally bound to consider the best interests of the child as the paramount consideration: as the ECHR has recently said in Yousef $v$ The Netherlands [2003] 1 FLR 210 (at para 73): "If any balancing of interests is necessary, the interests of the child must prevail." Vanessa Munro argued that this decision had broad-ranging implications, and she identified potential implications for sentencing policy, the rights of imprisoned fathers and the administration of mother and baby units. Since this decision, however, there have been several judicial review applications challenging the exercise of the discretion, one of the most publicised being that of Claire Frost.

In Claire $F_{V}$ Secretary of State for the Home Department [2004] EWHC 111 (Fam), the Prison Service had initially decided to separate her from her baby Lia-Jade at the age of nine months, rather than move them both to a different mother-and-baby unit until the baby reached 18 months, having taken the view that separation was better "earlier rather than later." The report of the judicial review decision indicates what can only be described as a shocking lack of professionalism on the part of the social worker who was responsible for representing the baby's interests at the Separation Board: she only became involved with the case on the day of the meeting, had not seen any relevant papers prior to arrival at the prison, and was described by Munby J as being "woefully unprepared for the task in hand."

Munby J took the view that, in this situation, the Prison Service should have adjourned the hearing (see "Making sure the child is heard", a lecture by the Hon Mr Justice Munby to the National Youth Advocacy Service on February 5, 2004 published in two parts in Amicus Curiae at (2004) issue 52, 2-8, and issue 53, 3-8). Munby J stressed the procedural unfairness in the decision-making process and quashed the decision to remove the baby at nine months, ruling it was a matter for the Prison Service to reconsider, and stressing the need for appropriate representation of the interests of the child. As a consequence, the baby was sent to live with her grandparents in May 2004 when she was 16 months old: Claire Frost has since been transferred to Askham Grange, 
the prison to which she had initially requested a transfer so the baby could stay with her up to the age of 18 months.

There is much which is thought-provoking about this case, and $R(D)$ v Secretary of State for the Home Department [2003] 1 FLR 979. In the public lecture referred to above, which was given shortly after his judgment in the Claire Frost case, Munby J argued that, in order to comply with the Convention, the Prison Service, or any other administrative decision-maker, has to ensure that the child's interests are adequately represented. He ends his detailed and through exposition of the law in "Making sure the child is heard" as follows:

"So I end where, in a sense, I began: with Article 8. It is fundamental to everything we do as professionals concerned with children and their families. It is something we all need to take very seriously, more seriously, perhaps, than sometimes we do. Unless we do, the voice of the child will not be heard."

These mother-and-baby cases, in contrast with the artificial insemination cases, demonstrate the beginning of judicial recognition of the voices of family members in prison decision-making. The Children Act requires the interests of the child to be paramount. Does this, therefore, mean that in the future, issues of the impact of prison service decisions on prisoners' children may be more readily brought to court? It is encouraging to read the text of Munby J's public lecture, when he reiterates the importance of listening to children. Broader issues exist in relation to the appropriateness of prison for women with young children, but discussion of potential alternatives, such as half-way houses, is outside the scope of this paper.

\section{CONCLUSIONS}

The term "prisoner's family" defines the family in relation to the inmate, and its usage could be challenged for that reason. However, it is appropriate when talking about law, since prisoners' families interactions with the law are governed by the courts' views of prisoners and their rights. Prisoners' partners become subject to an array of moral and social judgments when they seek to challenge Prison Service decisions, and the courts have not yet reconciled balancing the rights of family members with the interests of the Prison Service [or NOMS as it has become]. The cases involving babies indicate that at least certain judges are keen to preserve childrens' rights under Article 8: however, in the Re $P \& Q$ and Re Claire F cases, the judge was minded to maintain the discretionary power of the prison service in these matters.

The efforts of campaigners such as Mark Leech, and organisations such as Liberty and the Prison Reform Trust, have sought to encourage and facilitate prisoners' access to the courts in order to enforce their rights but the possibilities for legal challenges to preserve the rights of families have not yet been fully realised. The potential is there for the courts to adopt a rights-based approach to prisoners' families which challenges social stigmatisation and exclusion and which avoids punishing prisoners' partners and children: whether this will happen remains to be seen.

- This article is taken from the text of a lecture given at the Institute of Advanced Legal Studies on June 7, 2004

\section{Helen Codd}

Senior Lecturer in Law, Lancashire Law School, University of Central Lancashire, Preston 